\title{
Synthesis and Physico-Chemical Properties of Homoleptic Copper(I) Complexes with Asymmetric Ligands as a DSSC Dye
}

\author{
Tomohiko Inomata ${ }^{1, *}$, Mayuka Hatano ${ }^{1}$, Yuya Kawai ${ }^{1}$, Ayaka Matsunaga ${ }^{1}$, Takuma Kitagawa ${ }^{1}$, \\ Yuko Wasada-Tsutsui ${ }^{1}$, Tomohiro Ozawa ${ }^{1}$ and Hideki Masuda ${ }^{2, *(D)}$ \\ 1 Department of Life Science and Applied Chemistry, Graduate School of Engineering, Nagoya Institute of \\ Technology, Gokiso-cho, Showa-ku, Nagoya 466-8555, Japan; mable.tyo.pai.nmi@gmail.com (M.H.); \\ vip17742@gmail.com (Y.K.); ayaka.matsunaga@rolanddg.co.jp (A.M.); neymneym710@gmail.com (T.K.); \\ wasada.yuko@nitech.ac.jp (Y.W.-T.); ozawa.tomohiro@nitech.ac.jp (T.O.) \\ 2 Department of Applied Chemistry, Aichi Institute of Technology, 1247 Yachigusa, Yakusa-cho, \\ Toyota 470-0392, Japan \\ * Correspondence: tino@nitech.ac.jp (T.I.); masuda.hideki@aitech.ac.jp (H.M.)
}

\section{check for} updates

Citation: Inomata, T.; Hatano, M.; Kawai, Y.; Matsunaga, A.; Kitagawa, T.; Wasada-Tsutsui, Y.; Ozawa, T.; Masuda, H. Synthesis and Physico-Chemical Properties of Homoleptic Copper(I) Complexes with Asymmetric Ligands as a DSSC Dye. Molecules 2021, 26, 6835. https://doi.org/10.3390/ molecules26226835

Academic Editor: Alistair J. Lees

Received: 16 October 2021

Accepted: 10 November 2021

Published: 12 November 2021

Publisher's Note: MDPI stays neutral with regard to jurisdictional claims in published maps and institutional affiliations.

Copyright: (c) 2021 by the authors. Licensee MDPI, Basel, Switzerland. This article is an open access article distributed under the terms and conditions of the Creative Commons Attribution (CC BY) license (https:/ / creativecommons.org/licenses/by/ $4.0 /)$.

\begin{abstract}
To develop low-cost and efficient dye-sensitized solar cells (DSSCs), we designed and prepared three homoleptic $\mathrm{Cu}(\mathrm{I})$ complexes with asymmetric ligands, M1, M2, and Y3, which have the advantages of heteroleptic-type complexes and compensate for their synthetic challenges. The three copper(I) complexes were characterized by elemental analysis, UV-vis absorption spectroscopy, and electrochemical measurements. Their absorption spectra and orbital energies were evaluated and are discussed in the context of TD-DFT calculations. The complexes have high $V_{\text {OC }}$ values $(0.48$, 0.60 , and $0.66 \mathrm{~V}$ for M1, M2, and Y3, respectively) which are similar to previously reported copper(I) dyes with symmetric ligands, although their energy conversion efficiencies are relatively low $(0.17$, 0.64 , and $2.66 \%$, respectively).
\end{abstract}

Keywords: dye-sensitized solar cell; homoleptic $\mathrm{Cu}(\mathrm{I})$ complex dye; asymmetric ligand

\section{Introduction}

Dye-sensitized solar cells (DSSCs) are expected to play an important role as nextgeneration electricity sources because they have several advantages, such as low production cost and their ability to function under low light intensity [1,2]. However, they also have several disadvantages, such as poor durability and lower conversion efficiency compared to silicon-type solar cells. As a result, research efforts relevant to the improvement of DSSCs have been pursued [3-5]. A typical dye used in DSSCs is a ruthenium complex with a polypyridyl ligand, having a high energy conversion efficiency of over $11 \%$ [6]. Ruthenium is a relatively expensive transition metal. Therefore, ruthenium-free dyes, such as zinc(II)based dyes [7-9], and organic dyes [10-13], have been investigated. In recent years, some examples of alternative dyes have been confirmed as having high conversion efficiency comparable to ruthenium-based dyes $[9,13]$. Copper-based dyes have been investigated because they are much less expensive than ruthenium [14-28]. Typical copper(I) complexes tend to be stable under ambient atmosphere due to their tetrahedral structures. The presence of bulky substituent groups tends to enhance the stability of these complexes. The photochemical features of copper(I) complexes are similar to those of ruthenium(II) dyes, which have a strong absorbance contributing to a metal-to-ligand charge transfer (MLCT) [29]. A copper(I) complex dye with mesityl groups has been employed in a DSSC to provide high energy conversion efficiency of $4.66 \%$ [24]. Copper complexes have also been used as electrolytes for DSSCs employing their $\mathrm{Cu}$ (I/II) redox couples [30-32]. Furthermore, DSSCs in which both the dye and the electrolyte are composed of $\mathrm{Cu}$ complexes have been reported $[33,34]$. The two main types of DSSCs based on copper(I) complex dyes are classified as the homoleptic type $[14,15,17,18]$, and the heteroleptic type $[16,21,22,24]$. 
These two kinds of dyes are mainly composed of symmetric ligands. The homoleptic type is easily synthesized, but the introduction of distinct functional groups is challenging. The heteroleptic type has two different ligands that possess both functional and anchoring groups on the respective ligands. As a result, a high energy conversion efficiency is expected, but the synthesis of heteroleptic complexes in a solution is also challenging. The use of ligands with large substituents such as mesityl groups is essential in the synthesis of heteroleptic complexes. To solve this problem, a ligand with an attached anchor site is fixed to a surface, and then a $\mathrm{Cu}$ complex dye is constructed on the surface $[19,23,25,26]$. Therefore, the use of asymmetric ligands facilitates the synthesis of homoleptic complexes and creates a coordination environment similar to that of heteroleptic ligands without the use of large substituents. However, the conversion efficiency of DSSCs based on $\mathrm{Cu}(\mathrm{I})$ complex dyes with asymmetric ligands reported previously is very low [16]. To address the disadvantages of the previously reported copper(I) dyes, we designed and synthesized new asymmetric ligands, potassium I-2-cyano-3-(6,6'-dimethyl-2,2'-bipyridine4-yl)acrylate (L1), 2-(3-(4-(dimethylamino)phenyl)-1H-pyrazol-1-yl)-6-methylisonicotinic acid (L2), and 6,6'-dimethyl-2,2'-bipyridine-4-carboxylic acid (L3). The use of asymmetric ligands provides several advantages, such as reducing anchoring groups, routine synthesis, and convenient introduction of the functional groups.

In this study, we designed and synthesized new homoleptic copper(I) complexes with asymmetric ligands containing a cyano group as an electron-withdrawing group, M1, a dimethylaminophenyl group as an electron-donating group, $\mathbf{M} 2$, and lacking a special group, Y3 (Figure 1). A cyano group is occasionally included in organic dyes [10-13], to provide DSSCs with high conversion efficiency, accompanied by a red-shifted absorption band [35]. On the other hand, the $N, N$-dimethylaniline (DMA) group is used as an electrondonating group [36,37]. The introduction of these functional groups was expected to improve charge injection to oxide semiconductors. We synthesized these three asymmetric ligands, L1, L2, and L3 and the copper(I) complexes with an asymmetric ligand, M1, M2, and Y3. Measurements of UV-vis absorption spectra and TD-DFT calculations were carried out to evaluate energy conversion efficiencies. Furthermore, we prepared and evaluated DSSCs based on these complexes.

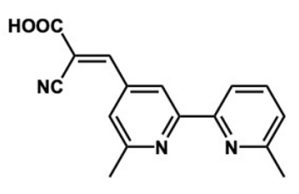

a)

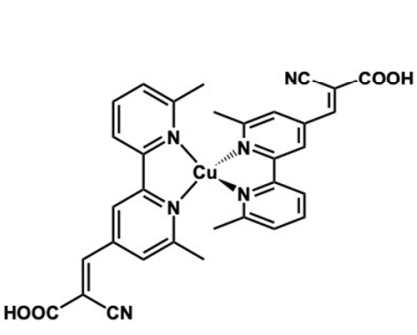

d)

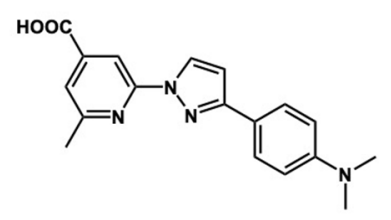

b)

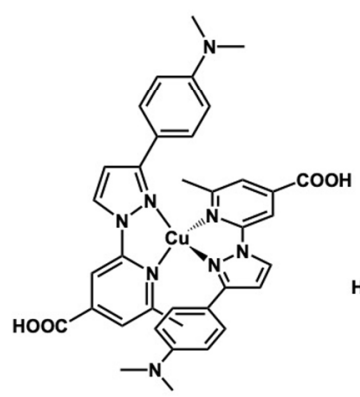

e)

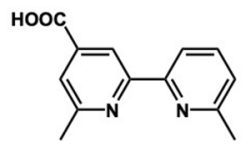

c)

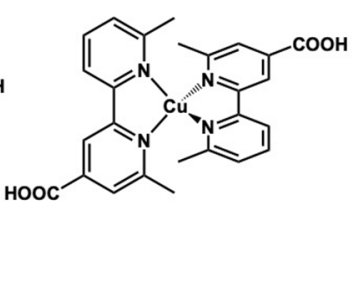

f)

Figure 1. Schematic structures of ligands, (a) L1, (b) L2, and (c) L3, and their Cu(I) complexes, (d) M1, (e) M2, and (f) Y3.

\section{Results and Discussion}

Synthesis and characterization of M1, M2, and Y3. The reactions of copper(II) sulfate and two equivalents of ligands, L1, L2, or Y3 accompanied by continuous treatment with ascorbic acid [15] gave homoleptic copper(I) complexes with asymmetric ligands, 
$\left[\mathrm{Cu}(\mathbf{L} \mathbf{1})_{2}\right] \mathrm{Cl}$ (purple crystal), $\left[\mathrm{Cu}(\mathbf{L} 2)_{2}\right] \mathrm{Cl}$ (deep yellow crystal), and $\left[\mathrm{Cu}(\mathbf{L} 3)_{2}\right] \mathrm{Cl}$ (dark red crystal), respectively. The preparations of the corresponding copper(I) complexes were characterized by ${ }^{1} \mathrm{H}$ NMR, FT-IR, ESI-MS, and elemental analysis.

The ${ }^{1} \mathrm{H}-\mathrm{NMR}$ spectra of $\mathbf{M 1}, \mathbf{M} 2$, and $\mathrm{Y}_{3}$ in $\mathrm{CD}_{3} \mathrm{OD}$ are shown in Figure S1. The ${ }^{1} \mathrm{H}$ peaks of the complexes are shifted by the coordination to copper(I) compared to their ligand peaks. Some of the hydrogen peaks of the coordinated ligands are shifted to a lower field region, and the methyl and methylene peaks of the ligands move to an upper field region. The former arises from the coordination of ligands to metal, and the latter results from the ring current effect caused by the approach of the ligand molecules during the formation of homoleptic complexes.

Furthermore, M1 has a $\mathrm{C} \equiv \mathrm{N}$ stretching vibration at $2221 \mathrm{~cm}^{-1}$ and a $\mathrm{C}=\mathrm{O}$ stretching vibration at $1703 \mathrm{~cm}^{-1}$, which are not observed in ligand L1. For M2, the $\mathrm{C}=\mathrm{N}$ and $\mathrm{C}=\mathrm{O}$ stretching vibrations are shifted to a low wavenumber region $\left(1611\right.$ and $1.716 \mathrm{~cm}^{-1}$, respectively) compared with those of ligand $\mathbf{L} 2$. On the other hand, the $\mathrm{C}=\mathrm{O}$ stretching vibration of $\mathbf{Y} 3$ is observed at $1718 \mathrm{~cm}^{-1}$. Additionally, ESI-MS and elemental analysis clearly indicate the generation of M1, M2, and Y3.

UV-vis absorption spectra of M1, M2, and Y3. The UV-vis spectra and data of M1, M2, and Y3 are shown in Figure 2a and Table 1, respectively. The UV-vis absorption spectrum of M1 in EtOH has maximum absorption bands at $497 \mathrm{~nm}\left(\varepsilon=9330 \mathrm{M}^{-1} \cdot \mathrm{cm}^{-1}\right)$ and $317 \mathrm{~nm}\left(\varepsilon=23,200 \mathrm{M}^{-1} \cdot \mathrm{cm}^{-1}\right)$, which are assigned as the MLCT band $(\mathrm{Cu} \rightarrow$ bpy $)$ and the $\pi-\pi^{*}$ transition band of bpy, respectively. A similar MLCT band was observed for the previously reported copper(I) bipyridine complex $[14,18]$. The introduction of an electron-withdrawing cyano group will make a strong absorption band shift to the visible region, as expected for a candidate dye for DSSCs.

a)

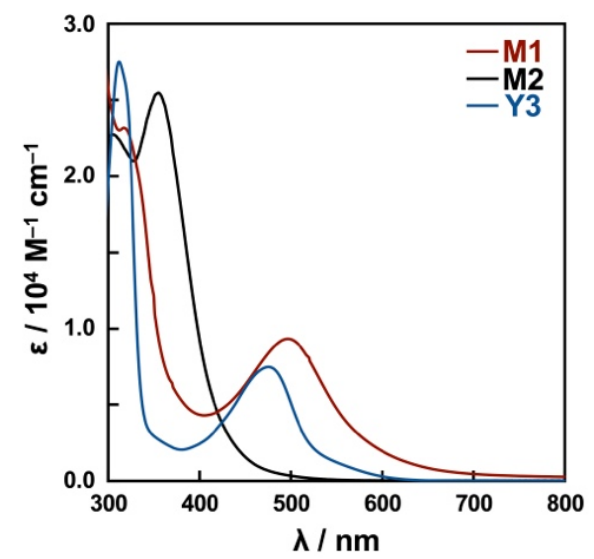

b)

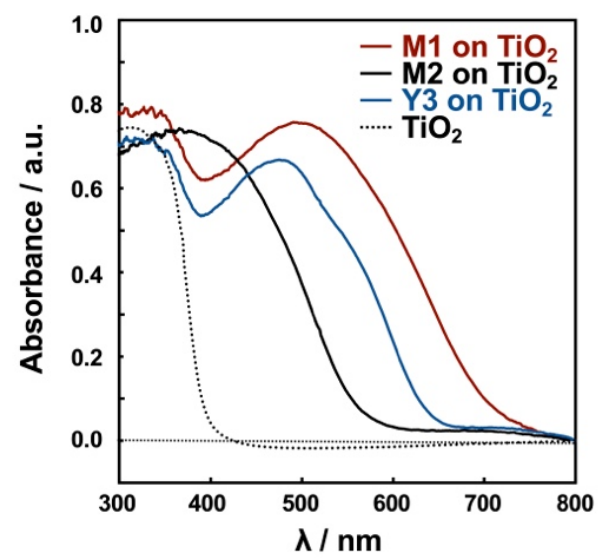

Figure 2. (a) UV-vis spectra of M1, M2, and $\mathbf{Y} 3$ in EtOH and (b) their DR spectra on $\mathrm{TiO}_{2}$.

Table 1. UV-vis and DR spectroscopic data for M1, M2, and Y3.

\begin{tabular}{|c|c|c|c|}
\hline \multirow{2}{*}{ Dye } & \multicolumn{2}{|c|}{ in $\mathrm{EtOH}$} & \multirow{2}{*}{$\frac{\text { on } \mathrm{TiO}_{2}}{\lambda_{\text {max }} / \mathrm{nm}}$} \\
\hline & $\begin{array}{c}\lambda / \mathrm{nm} \\
\left(\varepsilon / \mathbf{M}^{-1} \cdot \mathrm{cm}^{-1}\right)\end{array}$ & Assignment & \\
\hline M1 & $\begin{array}{c}317(23,200) \\
497(9330)\end{array}$ & $\begin{array}{c}\pi-\pi^{*}(\mathbf{L} \mathbf{1}) \\
\operatorname{MLCT}(\mathrm{Cu}(\mathrm{I}) \rightarrow \mathbf{L} \mathbf{1})\end{array}$ & 491 \\
\hline M2 & $355(25,500)$ & $\begin{array}{c}\pi-\pi^{*}(\mathbf{L} \mathbf{2}) \\
\operatorname{MLCT}(\mathrm{Cu}(\mathrm{I}) \rightarrow \mathbf{L} 2)\end{array}$ & 366 \\
\hline Y3 & $\begin{array}{c}312(27,500) \\
475(7480)\end{array}$ & $\begin{array}{c}\pi-\pi^{*}(\mathbf{L} \mathbf{3}) \\
\operatorname{MLCT}(\mathrm{Cu}(\mathrm{I}) \rightarrow \mathbf{L} \mathbf{3})\end{array}$ & 475 \\
\hline
\end{tabular}

For M2, the maximum absorption bands are located at $355 \mathrm{~nm}\left(\varepsilon=25,500 \mathrm{M}^{-1} \cdot \mathrm{cm}^{-1}\right)$, which overlap with the MLCT band $\left(\mathrm{Cu} \rightarrow\right.$ py) and $\pi-\pi^{*}$ transition band (dimethylaminophenyl 
$\rightarrow$ py). The MLCT band is significantly blue-shifted relative to that of M1. The introduction of electron-donating dimethylamino groups to the ligand results in a blue shift of the absorption band originating from the $\pi-\pi^{*}$ transition, relative to M1. The introduction of pyrazole as a $\pi$-electron-withdrawing group [38] results in a lowering of the $d$ orbital energy level. As a result, the maximum absorption band originating from MLCT was not identified in the visible region.

On the other hand, the spectrum of $\mathrm{Y} 3$ in EtOH has maximum absorption bands at $475 \mathrm{~nm}\left(\varepsilon=7480 \mathrm{M}^{-1} \cdot \mathrm{cm}^{-1}\right)$ and $312 \mathrm{~nm}\left(\varepsilon=27,500 \mathrm{M}^{-1} \cdot \mathrm{cm}^{-1}\right)$, which are assigned as the MLCT band ( $\mathrm{Cu} \rightarrow$ bpy) and the $\pi-\pi^{*}$ transition band of bpy, respectively. The spectrum of Y3 is similar to that of M1.

Diffuse reflectance (DR) spectra of $\mathbf{M 1}, \mathbf{M} 2$, and $\mathbf{Y} 3$ adsorbed on $\mathrm{TiO}_{2} /$ FTO electrodes, shown in Figure 2b, have broad bands at $491 \mathrm{~nm}$ for M1, $475 \mathrm{~nm}$ for Y3, and below $400 \mathrm{~nm}$ for M2, which are in the same general region as observed in solution $(497,475$ and $355 \mathrm{~nm}$ for M1, Y3, and M2, respectively) (Figure 2a), indicating that the coordination structures of M1, M2, and $\mathrm{Y} 3$ are retained on the $\mathrm{TiO}_{2} / \mathrm{FTO}$ electrodes.

Electrochemical properties of M1, M2, and Y3. To characterize the electrochemical properties of the copper(I) dyes, cyclic voltammetry measurements were carried out in solution and on the $\mathrm{TiO}_{2} /$ FTO electrode. The reversible and quasi-reversible redox potentials corresponding to $\mathrm{Cu}(\mathrm{I} / \mathrm{II})$ couple were detected at $-0.09 \mathrm{~V}\left(E_{\text {red }} / E_{\mathrm{ox}}=-0.38 / 0.20 \mathrm{~V}\right)$, $0.33 \mathrm{~V}\left(E_{\text {red }} / E_{\mathrm{ox}}=0.30 / 0.37 \mathrm{~V}\right)$, and $-0.03 \mathrm{~V}\left(E_{\text {red }} / E_{\mathrm{ox}}=-0.15 / 0.07 \mathrm{~V}\right) \mathrm{vs} . \mathrm{Fc} / \mathrm{Fc}^{+}$for M1, M2, and Y3 in DMF, respectively, as shown in Figure S3. The potentials are listed in Table 2 together with potentials converted to NHE standard [39-41]. In the previous reports, each potential in DMF was converted using $E_{1 / 2}\left(\mathrm{Fc} / \mathrm{Fc}^{+}\right)=0.58 \mathrm{~V}$ vs. NHE. For M1, the CV was measured in the presence of benzimidazole as the protonation agent, because two kinds of redox waves were observed in the absence of benzimidazole. Similar redox potentials were also obtained in the M1, M2, and Y3 dyes on the $\mathrm{TiO}_{2} /$ FTO electrode, as shown in Figure S4a-c, respectively. The values of $E_{1 / 2}$ for M1, M2, and $\mathbf{Y} 3$ on the $\mathrm{TiO}_{2} / \mathrm{FTO}$ electrode are $-0.10\left(E_{\text {red }} / E_{\text {ox }}=-0.39 / 0.19 \mathrm{~V}\right), 0.04\left(E_{\text {red }} / E_{\text {ox }}=-0.35 / 0.43 \mathrm{~V}\right)$, and -0.05 $\left(E_{\text {red }} / E_{\mathrm{ox}}=-0.39 / 0.29 \mathrm{~V}\right)$ vs. $\mathrm{Fc} / \mathrm{FC}^{+}$, respectively. The redox potentials of each dye vs. $\mathrm{Fc} / \mathrm{Fc}^{+}$and vs. NHE are summarized in Table 2. Each redox potential measured on $\mathrm{TiO}_{2}$ in acetonitrile was converted by $E_{1 / 2}\left(\mathrm{Fc} / \mathrm{Fc}^{+}\right)=0.62 \mathrm{~V}$ vs. NHE [42]. These findings indicate that the properties of the dyes in solution and on the $\mathrm{TiO}_{2} /$ FTO electrode are similar and are able to endure the structural change induced by the change in charge of the metal ion. However, in the case of $\mathbf{M} 2$, the reduction wave $\left(\mathrm{Cu}^{\mathrm{II}} \rightarrow \mathrm{Cu}^{\mathrm{I}}\right)$ is significantly shifted to the negative direction, indicating slow electron injection to $\mathbf{M} 2$ on the $\mathrm{TiO}_{2}$ surface. The relatively large current observed for $\mathbf{M} 2$ relative to other dyes is likely due to the greater amount of $\mathbf{M} 2$ adsorbed on $\mathrm{TiO}_{2}$ (Table S1). Thus, it appears that $\mathbf{M} 2$ dyes are aggregated on the $\mathrm{TiO}_{2}$ surface, resulting in the observation of the different redox behavior on the surface compared with that in solution.

Table 2. Redox potentials and $\Delta G$ values of M1, M2, and Y3.

\begin{tabular}{|c|c|c|c|c|c|c|}
\hline \multirow[b]{2}{*}{ Dye } & \multicolumn{3}{|c|}{ in Solution ${ }^{1}$} & \multicolumn{3}{|c|}{ on $\mathrm{TiO}_{2}{ }^{2}$} \\
\hline & $\begin{array}{c}E_{1 / 2} / \mathrm{V} \\
\text { vs. } \mathrm{Fc} / \mathrm{Fc}^{+}\end{array}$ & $\begin{array}{c}E_{1 / 2} / \mathrm{V} \\
\text { vs. NHE }\end{array}$ & $\Delta G / \mathrm{V}^{3}$ & $\begin{array}{c}E_{1 / 2} / \mathrm{V} \\
\text { vs. } \mathrm{Fc} / \mathrm{Fc}^{+}\end{array}$ & $\begin{array}{c}E_{1 / 2} / \mathrm{V} \\
\text { vs. NHE }\end{array}$ & $\Delta G / \mathrm{V}^{3}$ \\
\hline M1 & -0.09 & 0.49 & 0.09 & -0.10 & 0.52 & 0.12 \\
\hline M2 & 0.33 & 0.91 & 0.51 & 0.04 & 0.66 & 0.26 \\
\hline Y3 & -0.03 & 0.55 & 0.15 & -0.05 & 0.57 & 0.17 \\
\hline
\end{tabular}

${ }_{1}^{1}$ Scan rate: $0.2 \mathrm{~V} \mathrm{~s}^{-1}$ in DMF. ${ }^{2}$ Scan rate: $0.01 \mathrm{~V} \mathrm{~s}^{-1}$ in MeCN. ${ }^{3} \Delta G$ is defined as the difference in the redox potentials between $\mathrm{Cu}(\mathrm{I} / \mathrm{II})$ and $\mathrm{I}^{-} / \mathrm{I}^{3-}$.

Here, the redox potentials originating from the $\mathrm{Cu}(\mathrm{I} / \mathrm{II})$ couple generally correspond to the HOMO levels of the dyes. We defined the differences between the $E_{1 / 2}$ values corresponding to $\mathrm{Cu}(\mathrm{I} / \mathrm{II})$ of the dyes and the redox potential of $\mathrm{I}^{-} / \mathrm{I}_{3}{ }^{-} \mathrm{V}$ vs. NHE as $\Delta G$, which indicates a sufficient energy difference for efficient dye regeneration $[43,44]$. The $\Delta G$ 
values estimated for $\mathbf{M} 1$ and $\mathbf{Y} 3$ are low (0.09 and $0.15 \mathrm{~V}$ in DMF, respectively), suggesting that the driving force of $\mathbf{M} 1$ and $\mathbf{Y} 3$ dyes that are regenerated by triiodide is small. On the other hand, $\Delta G$ for M2 (0.51 V in DMF) is large. This value is similar to that of N719 in $\operatorname{DMF}(\Delta G=0.57 \mathrm{~V})$ [45]. It was previously reported that a $\Delta G$ value of $0.20-0.25 \mathrm{~V}$ is required to provide an efficient dye regeneration process using thiophen-based organic dyes and ferrocene derivatives as redox couples [42]. In the case of the [Co(bpy-pz $\left.)_{2}\right]^{2+}$ redox couple, the $\Delta G$ value is $0.25 \mathrm{~V}$ for triphenylamine-based organic dyes and for the Ru complex dye D35 [46]. The combination of Ru complex dyes and the $\mathrm{I}_{3}{ }^{-} / \mathrm{I}^{-}$redox couple provides a $\Delta G$ value $\approx 0.3 \mathrm{~V}$ [44]. Furthermore, it has recently been reported that the HOMO level of dyes for DSSCs is required to be near $0.5 \mathrm{~V}$ vs. SCE ( $0.75 \mathrm{~V}$ vs. NHE) to provide an efficient electron transfer process [44]. Therefore, the HOMO levels of the dyes will significantly influence the performance of DSSCs. The M1 and Y3 complexes used as dyes for DSSCs in this study will cause a slow dye regeneration process. For M2, the introduction of pyrazole groups into the ligand might lower the $d$ orbital energy level of copper. Indeed, the $E_{1 / 2}$ value corresponding to $\mathrm{Cu}(\mathrm{I} / \mathrm{II})$ for $\mathbf{M} 2$ was found to be lowered to $0.91 \mathrm{~V}$ vs. NHE in the DMF solution. Thus, it was expected that the use of $\mathbf{M} 2$ as a dye for DSSCs might give an optimal regeneration rate.

DFT calculations. To understand the absorption spectra and molecular orbital energies of the copper(I) complexes, TD-DFT calculations were performed for M1, M2, and Y3. The calculated absorption spectra and detailed data are shown in Figure 3 and Table 3, respectively. In these calculations, the counter anion $\mathrm{Cl}^{-}$, was not considered because it has been reported that the absence of the anion does not generally affect calculation results [17]. For the comparison of the calculated results with the experimental data, the molar extinction coefficients were not added. Instead, we focused on the calculated wavelengths and spectral patterns. In the calculated absorption spectra using B3LYP as the functional, the absorption maxima were found at $665 \mathrm{~nm}, 469 \mathrm{~nm}$, and $543 \mathrm{~nm}$ for M1, M2, and Y3, respectively, which differ significantly from the experimental absorption maxima ( $497 \mathrm{~nm}$, $355 \mathrm{~nm}$, and $475 \mathrm{~nm}$ for M1, M2, and Y3, respectively). However, when CAM-B3LYP was used as the functional, plausible absorption maxima were estimated at $471 \mathrm{~nm}$ and $334 \mathrm{~nm}$, and $431 \mathrm{~nm}$ for M1, M2, and Y3, respectively. The spectral patterns correspond well with the experimental patterns, as shown in Figure 3 and Table 3, respectively. With this confirmation, the spectral data calculated using CAM- B3LYP were employed for the discussion in this study. The molecular orbital diagram and orbital energy levels evaluated by the calculation using CAM-B3LYP are shown in Figures S5-S7 for M1, M2, and Y3, respectively. In the case of M1, HOMO-1 and HOMO are localized on the copper atom, and LUMO and LUMO+1 are localized on the pyridine ring containing carboxylate groups. A similar trend was also observed in the case of $\mathbf{Y} 3$. On the other hand, for M2, HOMO-3 and HOMO -2 are localized on the copper atom, HOMO-1 and HOMO are localized to dimethyl aminophenyl groups, and LUMO and LUMO+1 are localized on the pyridine ring containing carboxylate. These observations led us to expect an efficient excited electron transfer from the dyes to $\mathrm{TiO}_{2}$. With this expectation, the ratios of the electron distribution of carboxylic acid groups occupied on LUMO and LUMO+1 were estimated. The ratios are $8.8 \%$ and $9.3 \%$ for $\mathbf{M 1}, 20.0 \%$ and $20.9 \%$ for $\mathbf{M} 2$, and $12.9 \%$ and $12.9 \%$ for $\mathbf{Y} 3$, respectively. This indicates that $\mathbf{M} 2$ is more efficient for the electron transfer to the $\mathrm{TiO}_{2} /$ FTO electrode than $\mathbf{M} 1$ and $\mathbf{Y} 3$. 
a)
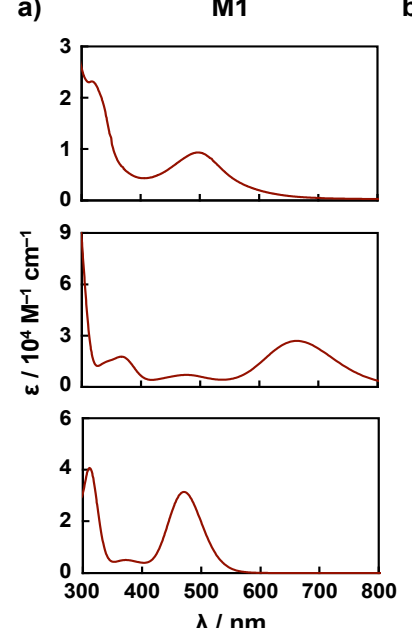

b)
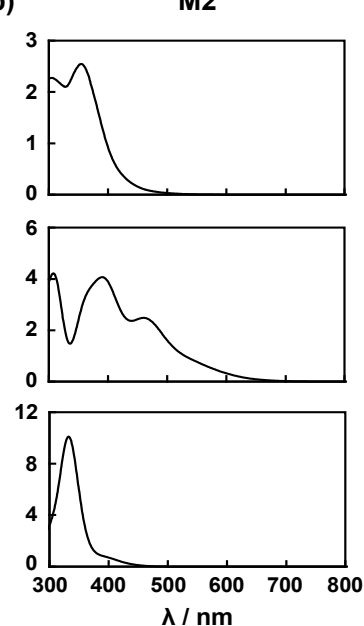

c)
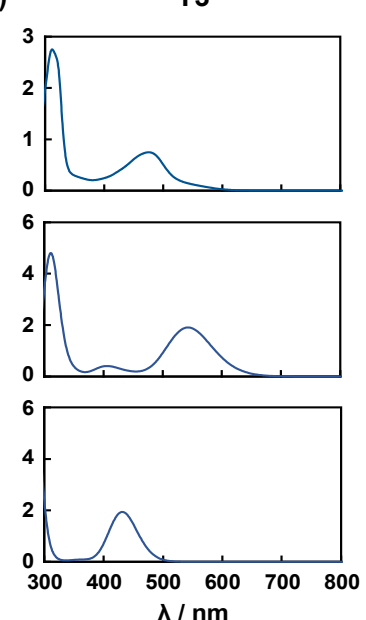

Figure 3. UV-vis absorption spectra of (a) M1, (b) M2, and (c) Y3 measured in EtOH (top), as calculated using B3LYP (middle) and CAM-B3LYP (bottom).

Table 3. UV-vis absorption spectroscopic data for M1, M2, and Y3 estimated by DFT calculations.

\begin{tabular}{|c|c|c|c|c|c|}
\hline Functional & Dye & $\begin{array}{c}\lambda_{\text {calc. }} \\
\mathrm{nm}\end{array}$ & f & Assignment & Character \\
\hline \multirow{3}{*}{ B3LYP } & M1 & 665 & 0.37 & $\begin{array}{l}\mathrm{HOMO}-1 \rightarrow \mathrm{LUMO}(44 \%) \\
\mathrm{HOMO} \rightarrow \mathrm{LUMO}+1(41 \%)\end{array}$ & MLCT \\
\hline & M2 & 469 & 0.23 & $\begin{array}{c}\mathrm{HOMO}-2 \rightarrow \text { LUMO }(44 \%) \\
\text { HOMO-3 } \rightarrow \text { LUMO+1 } \\
(35 \%)\end{array}$ & $\begin{array}{c}\mathrm{MLCT} \\
\pi-\pi^{*}\end{array}$ \\
\hline & Y3 & 543 & 0.26 & $\begin{array}{c}\text { HOMO } \rightarrow \text { LUMO }(50 \%) \\
\text { HOMO }-1 \rightarrow \text { LUMO+1 } \\
(49 \%)\end{array}$ & MLCT \\
\hline \multirow{3}{*}{ CAM-B3LYP } & M1 & 471 & 0.43 & $\begin{array}{c}\text { HOMO } \rightarrow \text { LUMO }(23 \%) \\
\text { HOMO }-1 \rightarrow \text { LUMO }(22 \%) \\
\text { HOMO }-1 \rightarrow \text { LUMO } 1 \\
\quad(21 \%) \\
\text { HOMO } \rightarrow \text { LUMO+1 }(17 \%)\end{array}$ & MLCT \\
\hline & M2 & 334 & 0.79 & $\begin{array}{c}\text { HOMO }-1 \rightarrow \text { LUMO+1 } \\
(22 \%) \\
\text { HOMO-2 } \rightarrow \text { LUMO (20\%) } \\
\text { HOMO } \rightarrow \text { LUMO (15\%) } \\
\text { HOMO-3 } \rightarrow \text { LUMO+1 } \\
(14 \%)\end{array}$ & $\begin{array}{l}\text { MLCT } \\
\pi-\pi^{*}\end{array}$ \\
\hline & Y3 & 431 & 0.27 & $\begin{array}{c}\mathrm{HOMO} \rightarrow \text { LUMO }(47 \%) \\
\text { HOMO-1 } \rightarrow \text { LUMO+1 } \\
(47 \%)\end{array}$ & MLCT \\
\hline
\end{tabular}

Photovoltaic performance. Under AM 1.5 sunlight, the photocurrent densityphotovoltage measurements were performed for M1, M2, and Y3. Figure 4 shows I-V curves under light and dark conditions. The details of obtained parameters are given in Table 4 . When the DSSC based on N719 was investigated under the same conditions, we obtained $7.83 \%$ as the conversion efficiency. Unfortunately, the energy conversion efficiencies for both dyes are very low. Although M1 has strong absorption in the visible region, the energy conversion efficiency is very low $(0.17 \%)$. This is reflected in the incident photon to current conversion efficiency (IPCE) spectrum (Figure S8). In particular, M1 has a lower energy conversion $(\mathrm{EQE}=0.7 \%$ at $480 \mathrm{~nm}$ ) around the maximum absorption band region (497 $\mathrm{nm}$ ). This may be due to a smaller driving force for dye regeneration, because 
it has a small contribution of the molecular orbital at the carboxylic acid site on LUMO and LUMO+1. M2 also has a low energy conversion efficiency ( $0.64 \%)$. This is rationalized by the fact that it does not have a large absorption band in the visible region. In addition, the amount of $\mathbf{M} 2$ adsorbed on $\mathrm{TiO}_{2} /$ FTO electrode is quite large (Table S1) and the adsorption structure of $\mathbf{M} 2$ is probably different. These cause a low conversion efficiency of the DSSC based on M2. On the other hand, Y3 has a large absorption band in the visible region, and its conversion efficiency is relatively high $(2.66 \%)$. The IPCE data show that the conversion efficiency of the visible area is also relatively high (EQE $=27 \%$ at $470 \mathrm{~nm}$ ) around the maximum absorption wavelength $(475 \mathrm{~nm})$. It was also confirmed that the molecular orbitals of the carboxylic acid moiety in $\mathrm{Y} 3$ as the adsorption site on $\mathrm{TiO}_{2}$ surface are localized on LUMO and LUMO+1 (Figure S7), resulting in a higher conversion efficiency than other dyes. Unfortunately, the DSSCs based on these dyes might be too inefficient. However, it is interesting that these DSSCs have high $V_{\mathrm{OC}}$ values $(0.48,0.60$, and $0.66 \mathrm{~V}$ for M1, M2, and Y3, respectively) in open circuit voltage measurements, which are at the top level among the copper complex-based DSSCs reported hitherto [14-16,18,21,22,24]. Provided that for these dyes, the anchoring groups are connected to $\mathrm{TiO}_{2}$, the structural change induced by the light excitation will be restrained, which will accelerate the electron transfer to the $\mathrm{TiO}_{2} /$ FTO electrode and inhibit the reverse electron transfer. FT-IR diffuse reflectance (DR) spectra of copper(I) dyes with asymmetric ligands that were adsorbed on $\mathrm{TiO}_{2}$ indicate the absence of free carboxylic acids. However, in the dye portion, it is expected that the two anchoring carboxylic acids are connected to $\mathrm{TiO}_{2}$. Therefore, regulation of structural changes may induce promotion of the electron transfer process and inhibition of the backward electron transfer to result in a high $V_{\mathrm{OC}}$. Among the homoleptic $\mathrm{Cu}$ complex dyes with asymmetric ligands, the conversion efficiency of solar cells with Y3 is relatively high, and it is possible to develop dyes with high $V_{\mathrm{OC}}$. Since heteroleptic copper complexes are difficult to synthesize, the development of homoleptic copper complexes with high efficiency using asymmetric ligands will be important.

a)

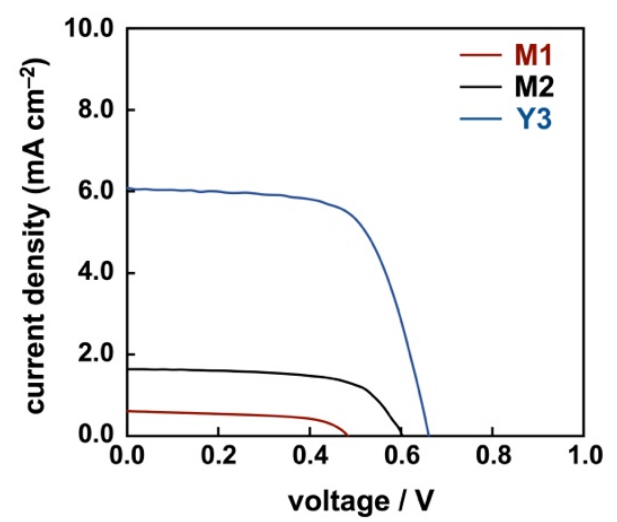

b)

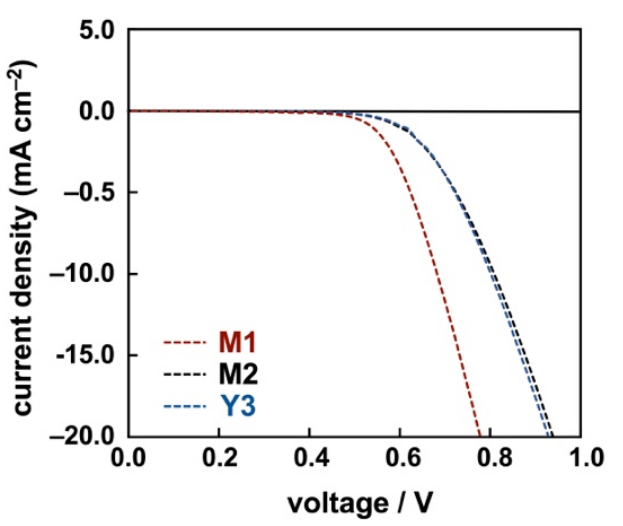

Figure 4. Current-voltage characteristics of dye-sensitized solar cells based on M1, M2, and Y3 (a) under irradiation and (b) in the dark.

Table 4. Photovoltaic performances of M1, M2, and Y3 ${ }^{1}$.

\begin{tabular}{ccccc}
\hline Dye & $V_{\text {oc }} / \mathbf{V}$ & $J_{\text {sc }} / \mathbf{m A} \cdot \mathbf{c m}^{-2}$ & $\boldsymbol{F F}$ & $\eta / \%$ \\
\hline M1 & 0.48 & 0.61 & 0.58 & 0.17 \\
M2 & 0.60 & 1.64 & 0.65 & 0.64 \\
Y3 & 0.66 & 6.08 & 0.66 & 2.66 \\
N719 & 0.69 & 16.5 & 0.69 & 7.83 \\
\hline
\end{tabular}

${ }^{1}$ The electrolyte composed of $0.1 \mathrm{M} \mathrm{LiI}, 0.05 \mathrm{M} \mathrm{I}_{2}, 0.6 \mathrm{M}$ 1,2-dimethyl-3-propylimidazolium iodide, and $0.5 \mathrm{M}$ 4-tert-butylpyridine in MeCN was adopted. 


\section{Materials and Methods}

General. ${ }^{1} \mathrm{H}$ NMR spectra were measured on a Varian Gemini-2000 XL-300 MHz FT spectrometer with TMS as an internal standard. Electronic absorption (UV-vis) spectra were recorded on a JASCO V-550 UV/vis spectrophotometer and diffuse reflection (DR) UV-vis spectra were recorded on a JASCO V-570 spectrophotometer. In the case of DR measurements, the absorption at $800 \mathrm{~nm}$ (a region without absorption bands) was subtracted from each spectrum to avoid the effect of differences in reflection coefficients. Infrared absorption spectra were measured on a JASCO FT/IR-410 instrument. Electrospray ionization mass spectra (ESI-MS) were measured using a Micromass LCT ESI-TOF mass spectrometer. Electrochemical measurements in solution were carried out in a three-electrode cell for complexes $(0.3 \mathrm{mM})$ dissolved in dry DMF containing 0.1 M TBAP (tetrabutylammonium perchlorate), a Pt wire used as a counter electrode, and an $\mathrm{Ag} / \mathrm{Ag}^{+}$electrode as a reference electrode. After the measurement, ferrocene $(\mathrm{Fc})$ was added as an internal reference. Electrochemical measurements on $\mathrm{TiO}_{2}$ were carried out using dyes on $\mathrm{TiO}_{2} / \mathrm{FTO}$ as working electrodes. The dyes on $\mathrm{TiO}_{2} / \mathrm{FTO}$ were prepared by immersing the $\mathrm{TiO}_{2}$ electrodes in $0.3 \mathrm{mM}$ EtOH solutions of M1, M2, Y3, and N719 for about $24 \mathrm{~h}$.

Chemicals. All reagents and organic solvents were purchased from Wako Pure Chemical Industries, TCI, Kanto Chemical, MERCK, and Sigma-Aldrich, and were used without further purification. Distilled water was obtained from an EYELA SA-2100E automated water distillation apparatus. N719 was purchased from Sigma-Aldrich.

Synthesis. The ligands L1, L2, and L3 were synthesized as carboxylate salts. Homoleptic copper(I) complexes with their ligands, $\left[\mathbf{C u}(\mathbf{L} 1)_{2}\right] \mathrm{Cl}(\mathbf{M} 1),\left[\mathrm{Cu}(\mathbf{L} 2)_{2}\right] \mathrm{Cl}(\mathbf{M} 2)$, and $\left[\mathrm{Cu}(\mathbf{L} 3)_{2}\right] \mathrm{Cl}(\mathbf{Y} 3)$ were prepared by the reaction of copper(II) sulfate and two equivalents of ligands (L1, L2, or L3), in the presence of ascorbic acid. Detailed synthetic methods for preparing the ligands and their $\mathrm{Cu}(\mathrm{I})$ complex dyes are described in the Supplementary Materials.

Fabrication of Solar cells. An FTO glass plate was washed in $\mathrm{MeCN}$ with an ultrasonic cleaning machine for $30 \mathrm{~min}$. The $\mathrm{TiO}_{2}$ paste (PST-18NR) was deposited as an adsorption layer of dye chromophore on the FTO glass plate, which was heated at $100{ }^{\circ} \mathrm{C}$ for $10 \mathrm{~min}$. The $\mathrm{TiO}_{2}$ paste (PST-400C) was coated as a light scattering layer, and the electrode was sintered at $530^{\circ} \mathrm{C}$ for $1 \mathrm{~h}$ and then immersed in a $0.3 \mathrm{mM}$ EtOH solution of $\mathbf{M} 1$ and $\mathbf{Y} 3$ for $24 \mathrm{~h}$. In the case of $\mathbf{M} 2, \mathrm{TiO}_{2}$ electrode was immersed in a $0.3 \mathrm{mM} \mathrm{MeOH}$ solution for $24 \mathrm{~h}$. The reference cell was prepared by immersing the plate in a $0.3 \mathrm{mM}$ EtOH solution of N719 for $24 \mathrm{~h}$. The platinum electrode was prepared by incubating the FTO plate coated with $30 \mathrm{mM}$ 2-propanol solution of $\mathrm{H}_{2} \mathrm{PtCl}_{6} \cdot 6 \mathrm{H}_{2} \mathrm{O}$ at $385^{\circ} \mathrm{C}$ for $30 \mathrm{~min}$. The $\mathrm{TiO}_{2}$ electrodes covered with dye and Pt electrode were pasted to each other using an epoxy-based adhesive and a UV cured resin. The electrolyte composed of $\operatorname{LiI}(0.1 \mathrm{M})$, $\mathrm{I}_{2}(0.05 \mathrm{M}), 1$,2-dimethyl-3-propylimidazolium iodide (0.6 M), and 4-tert-butylpyridine $(0.5 \mathrm{M})$ in $\mathrm{MeCN}$ was adopted.

Photovoltaic measurements. The photovoltaic performance of the DSSCs was assessed using an Asahi Spectra IVP-0605 current-voltage (I-V) curve measurement recorder using an Asahi Spectra HAL-302 solar simulator, which was focused on giving $100 \mathrm{mWcm}^{-2}$, the equivalent of one sun at $1.5 \mathrm{AM}$ at the surface of the test DSSCs. Incident phototo-current conversion efficiency (IPCE) spectra for DSSCs were recorded with a Newport benchtop optical power meter model 1936-R using an Asahi Spectra PVL-4000 EX3 wavelength-tunable light source. To unify the irradiation area, each DSSC was covered with black tape with a hole (area: $0.07 \mathrm{~cm}^{2}$ ) during measurements to minimize the influence of stray light.

Evaluation of the amount of each dye on $\mathrm{TiO}_{2} /$ FTO. After immersing the $\mathrm{TiO}_{2} / \mathrm{FTO}$ electrode in the $\mathrm{EtOH}$ solution of each dye, the adsorbed dye was desorbed as follows. For N719: by dipping the electrode into an $\mathrm{EtOH} / \mathrm{H}_{2} \mathrm{O}(1 / 1)$ solution containing $0.1 \mathrm{M} \mathrm{NaOH}$; for M1 and Y3: by dipping the electrode into an $\mathrm{EtOH} / \mathrm{H}_{2} \mathrm{O}(1 / 1)$ solution containing $1 \mathrm{mM} \mathrm{NaOH}$; for M2: by dipping the electrode into a $\mathrm{MeOH} / \mathrm{H}_{2} \mathrm{O}(1 / 1)$ solution containing $1 \mathrm{mM} \mathrm{NaOH}$. For $\mathrm{Cu}$ complex dyes, $1 \mathrm{mM} \mathrm{NaOH}$ aqueous solution was used because of 
these dyes are unstable under strongly basic conditions. The amount of dye on $\mathrm{TiO}_{2} / \mathrm{FTO}$ was estimated from UV/vis spectra of solutions containing desorbed dye.

Computational calculations. The calculations were performed with the Gaussian 09 program package [47]. We carried out all geometry optimizations in a vacuum state by density functional theory (DFT) [48-51] with B3LYP functional [52]. The following basis sets were used for the respective atoms; 6-311G for $\mathrm{Cu}$, augmented with two p-type polarization functions for the $4 p$ orbitals [53,54], 6-31G(d) [55-57] for the other atoms. To assign the absorption bands of electronic transitions in the complexes, time-dependent density functional theory (TD-DFT) [58] calculations were performed using the polarization conductor calculation model (CPCM) $[59,60]$ with B3LYP and the long-range corrected version of B3LYP using the Coulomb-attenuating method (CAM-B3LYP) [61]. In the TD-DFT calculations, the 70 lowest singlet-singlet excitation energies were adopted. We estimated the ratio of carboxylate occupied with any orbitals by using overlap integral [62-65] and molecular orbitals. The isosurfaces of the molecular orbitals were drawn using MOPLOT and MOVIEW programs $[66,67]$ on the Fujitsu CX400 system at the Nagoya University Information Technology Center. The electronic absorption spectra were calculated using AOMix-package-light [68] on the Windows 7 operating system.

\section{Conclusions}

In our efforts to synthesize $\mathrm{Cu}(\mathrm{I})$ complexes that have both advantages of homolepticand heteroleptic-type complexes and to overcome their disadvantages using substitutionally active copper(I) ion, we recognized that novel homoleptic complexes with asymmetric ligands should be synthesized. We designed and prepared three homoleptic copper(I) complex dyes with asymmetric ligands, M1, M2, and Y3, which have a small number of anchor groups. Although $\mathbf{M} 1$ has a strong absorption band in the visible region, the energy conversion efficiency of the DSSC based on M1 was found to be quite low. This might be explained by a small driving force and small contributions of LUMO and LUMO+1 on the carboxylic acid. The energy conversion efficiency of M2 was also found to be low, which might be due to low light harvesting capability. Otherwise, the introduction of pyrazole groups into the ligand in place of pyridine rings in M1 (0.62 V vs. NHE), as shown in the $\mathrm{CV}$ of $\mathbf{M} 2$ (1.04 V vs. NHE), causes the redox potential of $\mathrm{Cu}(\mathrm{I} / \mathrm{II})$ to shift to a positive region. This is important from the viewpoint of the dye regeneration process. In the case of $\mathbf{Y} 3$, its energy conversion efficiency is relatively high $(2.66 \%)$. We expect that the simple design of the L3 ligand causes delocalization of LUMO and LUMO+1 at the carboxylic acid as the anchor group, resulting in smooth electron transfer from the dye to the $\mathrm{TiO}_{2}$ electrode. It is very interesting that the DSSC based on copper(I) dyes with asymmetric ligands has high $V_{\mathrm{OC}}$ values $(0.48,0.60$, and $0.66 \mathrm{~V}$ for M1, M2, and Y3, respectively), although their energy conversion efficiencies are low. This may be caused by the introduction of asymmetric ligands. These findings provide useful insights into the design of new DSSC dyes in the future.

Supplementary Materials: The following materials are available online, Additional information for the detailed synthetic methods of all compounds, Figure S1: ${ }^{1} \mathrm{H}$ NMR spectra of (a) M1, (b) M2, and (c) Y3 in $\mathrm{CD}_{3} \mathrm{OD}$, Figure S2: ESI-MS spectra of (a) M1, (b) M2, and (c) Y3 in MeOH, Figure S3: Cyclic voltammograms of (a) M1 and (b) M2, and Y3, Figure S4: Cyclic voltammograms of (a) M1 and (b) M2, and $\mathbf{Y} 3$ on the $\mathrm{TiO}_{2} /$ FTO electrode, Figure S5: Isodensity surface plots of $\mathbf{M 1}$ in EtOH as calculated using CAM-B3LYP, Figure S6: Isodensity surface plots of M2 in EtOH as calculated using CAM-B3LYP, Figure S7: Isodensity surface plots of Y3 in EtOH as calculated using CAM-B3LYP, Figure S8: IPCE spectra of M1, M2 and Y3, Table S1: Amount of each dye adsorbed on the $\mathrm{TiO}_{2} / \mathrm{FTO}$ electrode. Table S1. Amount of each dye adsorbed on the $\mathrm{TiO}_{2} /$ FTO electrode.

Author Contributions: Conceptualization, T.I. and H.M.; methodology, T.I., T.K. and Y.W.-T.; theoretical calculations, M.H. and Y.W.-T.; validation, T.I. and T.O.; formal analysis, M.H., Y.K. and A.M.; investigation, M.H., Y.K. and A.M; data curation, M.H., Y.K. and A.M.; writing-original draft preparation, H.M.; writing-review and editing, T.I. and H.M.; visualization, T.I.; supervision, T.I. 
and T.O.; project administration, H.M.; funding acquisition, H.M. All authors have read and agreed to the published version of the manuscript.

Funding: This work was partly supported by the Japan Society for the Promotion of Science (JSPS, 20H02752) through the Program for Advancing Strategic International Networks to Accelerate the Circulation of Talented Researchers and a Grant-in-Aid for JSPS Fellows for their financial supports.

Institutional Review Board Statement: Not applicable.

Informed Consent Statement: Not applicable.

Data Availability Statement: The data presented in this study is contained within this article and is supported by data in the Supplementary Materials.

Conflicts of Interest: The authors declare no conflict of interest.

Sample Availability: Samples are not available from the corresponding authors.

\section{References}

1. Grätzel, M. Photoelectrochemical cells. Nature 2001, 414, 338-344. [CrossRef]

2. Grätzel, M. Solar cells to dye for. Nature 2003, 421, 586-587. [CrossRef]

3. Wang, P.; Zakeeruddin, S.M.; Moser, J.E.; Nazeeruddin, M.K.; Sekiguchi, T.; Grätzel, M. A stable quasi-solid-state dye-sensitized solar cell with an amphiphilic ruthenium sensitizer and polymer gel electrolyte. Nat. Mater. 2003, 2, 402-407. [CrossRef]

4. Son, H.-J.; Prasittichai, C.; Mondloch, J.E.; Luo, L.; Wu, J.; Kim, D.W.; Farha, O.K.; Hupp, J.T. Dye stabilization and enhanced photoelectrode wettability in water-based dye-sensitized solar cells through post-assembly atomic layer deposition of $\mathrm{TiO}_{2}$. J. Am. Chem. Soc. 2013, 135, 11529-11532. [CrossRef]

5. Manfredi, N.; Bianchi, A.; Causin, V.; Ruffo, R.; Simonutti, R.; Abbotto, A. Electrolytes for quasi solid-state dye-sensitized solar cells based on block copolymers. J. Polym. Sci. Part A Polym. Chem. 2014, 52, 719-727. [CrossRef]

6. Nazeeruddin, M.K.; De Angelis, F.; Fantacci, S.; Selloni, A.; Viscardi, G.; Liska, P.; Ito, S.; Bessho, T.; Gratzel, M. Combined Experimental and DFT-TDDFT Computational Study of Photoelectrochemical Cell Ruthenium Sensitizers. J. Am. Chem. Soc. 2013, 127, 16835-16847. [CrossRef] [PubMed]

7. Yella, A.; Lee, H.-W.; Tsao, H.N.; Yi, C.; Chandiran, A.K.; Nazeeruddin, M.K.; Diau, E.W.-G.; Yeh, C.-Y.; Zakeeruddin, S.M.; Grätzel, M. Porphyrin-Sensitized Solar Cells with Cobalt (II/III)-Based Redox Electrolyte Exceed 12 Percent Efficiency. Science 2011, 334, 629-634. [CrossRef] [PubMed]

8. Bozic-Weber, B.; Constable, E.C.; Hostettler, N.; Housecroft, C.E.; Schmitt, R.; Schonhofer, E. The d10 route to dye-sensitized solar cells: Step-wise assembly of zinc(II) photosensitizers on $\mathrm{TiO}_{2}$ surfaces. Chem. Commun. 2012, 48, 5727-5729. [CrossRef]

9. Mathew, S.; Yella, A.; Gao, P.; Humphry-Baker, R.; Curchod, B.F.; Ashari-Astani, N.; Tavernelli, I.; Rothlisberger, U.; Nazeeruddin, M.K.; Gratzel, M. Dye-sensitized solar cells with 13\% efficiency achieved through the molecular engineering of porphyrin sensitizers. Nat. Chem. 2014, 6, 242-247. [CrossRef] [PubMed]

10. Hwang, S.; Lee, J.H.; Park, C.; Lee, H.; Kim, C.; Park, C.; Lee, M.H.; Lee, W.; Park, J.; Kim, K.; et al. A highly efficient organic sensitizer for dye-sensitized solar cells. Chem. Commun. 2007, 46, 4887-4889. [CrossRef]

11. Wang, Z.-S.; Cui, Y.; Dan-oh, Y.; Kasada, C.; Shinpo, A.; Hara, K. Thiophene-Functionalized Coumarin Dye for Efficient DyeSensitized Solar Cells: Electron Lifetime Improved by Coadsorption of Deoxycholic Acid. J. Phys. Chem. C 2007, 111, 7224-7230. [CrossRef]

12. Choi, H.; Baik, C.; Kang, S.O.; Ko, J.; Kang, M.S.; Nazeeruddin, M.K.; Gratzel, M. Highly efficient and thermally stable organic sensitizers for solvent-free dye-sensitized solar cells. Angew. Chem. Int. Ed. Engl. 2008, 47, 327-330. [CrossRef] [PubMed]

13. Yella, A.; Humphry-Baker, R.; Curchod, B.F.E.; Ashari Astani, N.; Teuscher, J.; Polander, L.E.; Mathew, S.; Moser, J.-E.; Tavernelli, I.; Rothlisberger, U.; et al. Molecular Engineering of a Fluorene Donor for Dye-Sensitized Solar Cells. Chem. Mater. 2013, 25, 2733-2739. [CrossRef]

14. Bessho, T.; Constable, E.C.; Graetzel, M.; Hernandez Redondo, A.; Housecroft, C.E.; Kylberg, W.; Nazeeruddin, M.K.; Neuburger, M.; Schaffner, S. An element of surprise-efficient copper-functionalized dye-sensitized solar cells. Chem. Commun. 2008, 32, 3717-3719. [CrossRef] [PubMed]

15. Constable, E.C.; Hernandez Redondo, A.; Housecroft, C.E.; Neuburger, M.; Schaffner, S. Copper(I) complexes of 6,6'-disubstituted 2,2'-bipyridine dicarboxylic acids: New complexes for incorporation into copper-based dye sensitized solar cells (DSCs). Dalton Trans. 2009, 33, 6634-6644. [CrossRef]

16. Bozic-Weber, B.; Constable, E.C.; Housecroft, C.E.; Neuburger, M.; Price, J.R. Sticky complexes: Carboxylic acid-functionalized $\mathrm{N}$-phenylpyridin-2-ylmethanimine ligands as anchoring domains for copper and ruthenium dye-sensitized solar cells. Dalton Trans. 2010, 39, 3585-3594. [CrossRef]

17. Bozic-Weber, B.; Chaurin, V.; Constable, E.C.; Housecroft, C.E.; Meuwly, M.; Neuburger, M.; Rudd, J.A.; Schonhofer, E.; Siegfried, L. Exploring copper(I)-based dye-sensitized solar cells: A complementary experimental and TD-DFT investigation. Dalton Trans. 2012, 41, 14157-14169. [CrossRef] 
18. Yuan, Y.J.; Yu, Z.T.; Zhang, J.Y.; Zou, Z.G. A copper(I) dye-sensitised TiO2-based system for efficient light harvesting and photoconversion of $\mathrm{CO}_{2}$ into hydrocarbon fuel. Dalton Trans. 2012, 41, 9594-9597. [CrossRef]

19. Ashbrook, L.N.; Elliott, C.M. Dye-Sensitized Solar Cell Studies of a Donor-Appended Bis(2,9-dimethyl-1,10-phenanthroline) Cu(I) Dye Paired with a Cobalt-Based Mediator. J. Phys. Chem. C 2013, 117, 3853-3864. [CrossRef]

20. Wills, K.A.; Mandujano-Ramírez, H.J.; Merino, G.; Mattia, D.; Hewat, T.; Robertson, N.; Oskam, G.; Jones, M.D.; Lewis, S.E.; Cameron, P.J. Investigation of a copper(i) biquinoline complex for application in dye-sensitized solar cells. RSC Adv. 2013, 3, 23361-23369. [CrossRef]

21. Bozic-Weber, B.; Brauchli, S.Y.; Constable, E.C.; Furer, S.O.; Housecroft, C.E.; Wright, I.A. Hole-transport functionalized copper(I) dye sensitized solar cells. Phys. Chem. Chem. Phys. 2013, 15, 4500-4504. [CrossRef]

22. Brauchli, S.Y.; Bozic-Weber, B.; Constable, E.C.; Hostettler, N.; Housecroft, C.E.; Zampese, J.A. Factors controlling the photoresponse of copper(i) diimine dyes containing hole-transporting dendrons in dye-sensitized solar cells: Substituent and solvent effects. RSC Adv. 2014, 4, 34801-34815. [CrossRef]

23. Hewat, T.E.; Yellowlees, L.J.; Robertson, N. Neutral copper(I) dipyrrin complexes and their use as sensitizers in dye-sensitized solar cells. Dalton Trans. 2014, 43, 4127-4136. [CrossRef]

24. Sandroni, M.; Favereau, L.; Planchat, A.; Akdas-Kilig, H.; Szuwarski, N.; Pellegrin, Y.; Blart, E.; Le Bozec, H.; Boujtita, M.; Odobel, F. Heteroleptic copper(i)-polypyridine complexes as efficient sensitizers for dye sensitized solar cells. J. Mater. Chem. A 2014, 2, 9944-9947. [CrossRef]

25. Brauchli, S.Y.; Constable, E.C.; Housecroft, C.E. Concentration effects on the performance of bis(diimine) copper(I) dyes in dye-sensitized solar cells. Dyes Pigment. 2015, 113, 447-450. [CrossRef]

26. Housecroft, C.E.; Constable, E.C. The emergence of copper(I)-based dye sensitized solar cells. Chem. Soc. Rev. 2015, 44, 8386-8398. [CrossRef]

27. Tsaturyan, A.; Machida, Y.; Akitsu, T.; Gozhikova, I.; Shcherbakov, I. Binaphthyl-containing Schiff base complexes with carboxyl groups for dye sensitized solar cell: An experimental and theoretical study. J. Mol. Struct. 2018, 1162, 54-62. [CrossRef]

28. Liu, Y.; Yiu, S.-C.; Ho, C.-L.; Wong, W.-Y. Recent advances in copper complexes for electrical/light energy conversion. Coord. Chem. Rev. 2018, 375, 514-557. [CrossRef]

29. Armaroli, N. Photoactive mono- and polynuclear $\mathrm{Cu}(\mathrm{i})$-phenanthrolines. A viable alternative to Ru(ii)-polypyridines? Chem. Soc. Rev. 2001, 30, 113-124. [CrossRef]

30. Colombo, A.; Dragonetti, C.; Magni, M.; Roberto, D.; Demartin, F.; Caramori, S.; Bignozzi, C.A. Efficient copper mediators based on bulky asymmetric phenanthrolines for DSSCs. ACS Appl. Mater. Interfaces 2014, 6, 13945-13955. [CrossRef] [PubMed]

31. Cao, Y.; Saygili, Y.; Ummadisingu, A.; Teuscher, J.; Luo, J.; Pellet, N.; Giordano, F.; Zakeeruddin, S.M.; Moser, J.E.; Freitag, M.; et al. 11\% efficiency solid-state dye-sensitized solar cells with copper(II/I) hole transport materials. Nat. Commun. 2017, 8, 15390. [CrossRef]

32. Colombo, A.; Dragonetti, C.; Roberto, D.; Fagnani, F. Copper Complexes as Alternative Redox Mediators in Dye-Sensitized Solar Cells. Molecules 2021, 26, 194. [CrossRef] [PubMed]

33. Dragonetti, C.; Magni, M.; Colombo, A.; Fagnani, F.; Roberto, D.; Melchiorre, F.; Biagini, P.; Fantacci, S. Towards efficient sustainable full-copper dye-sensitized solar cells. Dalton Trans. 2019, 48, 9703-9711. [CrossRef]

34. Colombo, A.; Dragonetti, C.; Fagnani, F.; Roberto, D.; Melchiorre, F.; Biagini, P. Improving the efficiency of copper-dye-sensitized solar cells by manipulating the electrolyte solution. Dalton Trans. 2019, 48, 9818-9823. [CrossRef]

35. Hara, K.; Tachibana, Y.; Ohga, Y.; Shinpo, A.; Suga, S.; Sayama, K.; Sugihara, H.; Arakawa, H. Dye-sensitized nanocrystalline TiO2 solar cells based on novel coumarin dyes. Sol. Energy Mater. Sol. Cells 2003, 77, 89-103. [CrossRef]

36. Hara, K.; Kurashige, M.; Ito, S.; Shinpo, A.; Suga, S.; Sayama, K.; Arakawa, H. Novel polyene dyes for highly efficient dyesensitized solar cells. Chem. Commun. 2003, 2, 252-253. [CrossRef] [PubMed]

37. Lu, J.; Xu, X.; Cao, K.; Cui, J.; Zhang, Y.; Shen, Y.; Shi, X.; Liao, L.; Cheng, Y.; Wang, M. D- $\pi$-A structured porphyrins for efficient dye-sensitized solar cells. J. Mater. Chem. A 2013, 1, 10008-10015. [CrossRef]

38. Yum, J.H.; Baranoff, E.; Kessler, F.; Moehl, T.; Ahmad, S.; Bessho, T.; Marchioro, A.; Ghadiri, E.; Moser, J.E.; Yi, C.; et al. A cobalt complex redox shuttle for dye-sensitized solar cells with high open-circuit potentials. Nat. Commun. 2012, 3, 631. [CrossRef]

39. Connelly, N.G.; Geiger, W.E. Chemical Redox Agents for Organometallic Chemistry. Chem. Rev. 1996, 96, 877-910. [CrossRef] [PubMed]

40. Noviandri, I.; Brown, K.N.; Fleming, D.S.; Gulyas, P.T.; Lay, P.A.; Masters, A.F.; Phillips, L. The Decamethylferrocenium/Decamethylferrocene Redox Couple: A Superior Redox Standard to the Ferrocenium/Ferrocene Redox Couple for Studying Solvent Effects on the Thermodynamics of Electron Transfer. J. Comput. Chem. B 1999, 101, 6713-6722. [CrossRef]

41. Pavlishchuk, V.V.; Addison, A.W. Conversion constants for redox potentials measured versus different reference electrodes in acetonitrile solutions at $25^{\circ} \mathrm{C}$. Inorg. Chim. Acta 2000, 298, 97-102. [CrossRef]

42. Daeneke, T.; Mozer, A.J.; Uemura, Y.; Makuta, S.; Fekete, M.; Tachibana, Y.; Koumura, N.; Bach, U.; Spiccia, L. Dye regeneration kinetics in dye-sensitized solar cells. J. Am. Chem. Soc. 2012, 134, 16925-16928. [CrossRef]

43. Zervaki, G.E.; Roy, M.S.; Panda, M.K.; Angaridis, P.A.; Chrissos, E.; Sharma, G.D.; Coutsolelos, A.G. Efficient sensitization of dye-sensitized solar cells by novel triazine-bridged porphyrin-porphyrin dyads. Inorg. Chem. 2013, 52, 9813-9825. [CrossRef]

44. Funaki, T.; Otsuka, H.; Onozawa-Komatsuzaki, N.; Kasuga, K.; Sayama, K.; Sugihara, H. Systematic evaluation of HOMO energy levels for efficient dye regeneration in dye-sensitized solar cells. J. Mater. Chem. A 2014, 2, 15945-15951. [CrossRef] 
45. Mishra, A.; Pootrakulchote, N.; Fischer, M.K.; Klein, C.; Nazeeruddin, M.K.; Zakeeruddin, S.M.; Bauerle, P.; Gratzel, M. Design and synthesis of a novel anchoring ligand for highly efficient thin film dye-sensitized solar cells. Chem. Commun. 2009, 46, 7146-7148. [CrossRef] [PubMed]

46. Feldt, S.M.; Lohse, P.W.; Kessler, F.; Nazeeruddin, M.K.; Gratzel, M.; Boschloo, G.; Hagfeldt, A. Regeneration and recombination kinetics in cobalt polypyridine based dye-sensitized solar cells, explained using Marcus theory. Phys. Chem. Chem. Phys. 2013, 15, 7087-7097. [CrossRef] [PubMed]

47. Frisch, M.J.; Trucks, G.W.; Schlegel, H.B.; Scuseria, G.E.; Robb, M.A.; Cheeseman, J.R.; Scalmani, G.; Barone, V.; Petersson, G.A.; Nakatsuji, H.; et al. Gaussian 09, Revision A.02; Gaussian, Inc.: Wallingford, CT, USA, 2016.

48. Hohenberg, P.; Kohn, W. Inhomogeneous Electron Gas. Phys. Rev. 1964, 136, B864-B871. [CrossRef]

49. Kohn, W.; Sham, L.J. Self-Consistent Equations Including Exchange and Correlation Effects. Phys. Rev. 1965, 140, A1133-A1138. [CrossRef]

50. Parr, R.G.; Yang, W. Density-Functional Theory of Atoms and Molecules; Oxford University Press: New York, NY, USA, 1989.

51. Dennis, R.S.; Michael, C.Z. The Challenge of $d$ and $f$ Electrons. Theory and Computation; ACS: Washington, DC, USA, 1989.

52. Becke, A.D. Density-functional thermochemistry. III. The role of exact exchange. J. Chem. Phys. 1993, 98, 5648-5652. [CrossRef]

53. Wachters, A.J.H. Gaussian Basis Set for Molecular Wavefunctions Containing Third-Row Atoms. J. Chem. Phys. 1970, 52, 1033-1036. [CrossRef]

54. Raghavachari, K.; Trucks, G.W. Highly correlated systems. Excitation energies of first row transition metals Sc-Cu. J. Chem. Phys. 1989, 91, 1062-1065. [CrossRef]

55. Hehre, W.J.; Ditchfield, R.; Pople, J.A. Self-Consistent Molecular Orbital Methods. XII. Further Extensions of Gaussian-Type Basis Sets for Use in Molecular Orbital Studies of Organic Molecules. J. Chem. Phys. 1972, 56, 2257-2261. [CrossRef]

56. Hariharan, P.C.; Pople, J.A. The Influence of Polarization Functions on Molecular Orbital Hydrogenation Energies. Theor. Chem. Acc. 1973, 28, 213-222. [CrossRef]

57. Frisch, M.J.; Pople, J.A.; Binkley, J.S. Self-consistent molecular orbital methods 25. Supplementary functions for Gaussian basis sets. J. Chem. Phys. 1984, 80, 3265-3269. [CrossRef]

58. Dreuw, A.; Head-Gordon, M. Single-Reference ab Initio Methods for the Calculation of Excited States of Large Molecules. Chem. Rev. 2005, 105, 4009-4037. [CrossRef]

59. Barone, V.; Cossi, M. Quantum Calculation of Molecular Energies and Energy Gradients in Solution by a Conductor Solvent Model. J. Phys. Chem. 1998, 102, 1995-2001. [CrossRef]

60. Cossi, M.; Rega, N.; Scalmani, G.; Barone, V. Energies, Structures, and Electronic Properties of Molecules in Solution with the C-PCM Solvation Model. J. Comput. Chem. 2003, 24, 669-681. [CrossRef] [PubMed]

61. Yanai, T.; Tew, D.P.; Handy, N.C. A new hybrid exchange-correlation functional using the Coulomb-attenuating method (CAM-B3LYP). Chem. Phys. Lett. 2004, 393, 51-57. [CrossRef]

62. Mulliken, R.S. Electronic Population Analysis on LCAO-MO Molecular Wave Functions. I. J. Chem. Phys. 1955, 23, 1833-1840. [CrossRef]

63. Mulliken, R.S. Electronic Population Analysis on LCAO-MO Molecular Wave Functions. II. Overlap Populations, Bond Orders, and Covalent Bond Energies. J. Chem. Phys. 1955, 23, 1841-1846. [CrossRef]

64. Mulliken, R.S. Electronic Population Analysis on LCAO-MO Molecular Wave Functions. III. Effects of Hybridization on Overlap and Gross AO Populations. J. Chem. Phys. 1955, 23, 2338-2342. [CrossRef]

65. Mulliken, R.S. Electronic Population Analysis on LCAO-MO Molecular Wave Functions. IV. Bonding and Antibonding in LCAO and Valence-Bond Theories. J. Chem. Phys. 1955, 23, 2343-2346. [CrossRef]

66. Wasada, H.; Tsutsui, Y. Bull. Fac. General Educ.; Gifu University: Gifu, Japan, 1996; Volume 33, pp. 145-158.

67. Takahashi, I.; Wasada, H.; Tsutsui, Y. MOVIEW; Representing Molecular Orbitals and Electron Density Maps by Isosurfaces A Program; Nagoya University Information Technology Center: Nagoya, Japan, 1996.

68. Gorelsky, S.I. AOMix Version 6.85. Available online: http:/ / www.sg-chem.net/ (accessed on 16 October 2021). 